\title{
Effects of azoxystrobin, chlorothalonil, and ethoprophos on the reproduction of three terrestrial invertebrates using a natural Mediterranean soil
}

\author{
Sara Leitão ${ }^{\mathrm{a}, *}$, M. José Cerejeira ${ }^{\mathrm{a}}$, Paul J. Van den Brink ${ }^{\mathrm{b}, \mathrm{c}}$, José Paulo Sousa ${ }^{\mathrm{d}}$ \\ a Instituto Superior de Agronomia, University of Lisbon, Centro de Engenharia dos Biossistemas (CEER), Tapada da Ajuda, 1349-017 Lisboa, Portugal \\ ${ }^{\mathrm{b}}$ Department of Aquatic Ecology and Water Quality Management, Wageningen University, Wageningen University and Research centre, P.O. Box 47, \\ 6700AA Wageningen, The Netherlands \\ ${ }^{c}$ Alterra, Wageningen University and Research centre, P. O. box 47, 6700AA Wageningen, The Netherlands \\ d IMAR-CMA, Department of Life Science, University of Coimbra, Apartado 3046, 3001-401 Coimbra, Portugal
}

\section{A R T I C L E I N F O}

\section{Article history:}

Received 31 July 2013

Received in revised form

20 December 2013

Accepted 27 December 2013

\section{Keywords:}

Pesticides

Non-target soil organisms

Natural soil

Mediterranean conditions

Ecotoxicity

\begin{abstract}
A B S T R A C T
The potential terrestrial toxicity of three pesticides, azoxystrobin, chlorothalonil, and ethoprophos was evaluated using reproduction ecotoxicological tests with different non-target species: the collembolan Folsomia candida, the earthworm Eisenia andrei, and the enchytraeid Enchytraeus crypticus. All reproduction tests were performed with natural soil from a Mediterranean agricultural area (with no pesticide residues) in order to improve the relevance of laboratory data to field conditions. Controls were performed with natural and standard artificial soil (OECD 10\% OM). The fungicide azoxystrobin showed the highest toxicity to earthworms $\left(\mathrm{EC}_{50}=42.0 \mathrm{mg}\right.$ a.i. $\mathrm{kg}^{-1} \mathrm{dw}$ soil). Collembolans were the most sensitive taxa in terms of sublethal effects of chlorothalonil with an $\mathrm{EC}_{50}$ of $31.1 \mathrm{mg}$ a.i. $\mathrm{kg}^{-1} \mathrm{dw}$ soil followed by the earthworms with an $\mathrm{EC}_{50}$ of $40.9 \mathrm{mg}$ a.i. $\mathrm{kg}^{-1} \mathrm{dw}$ soil. The insecticide ethoprophos was the most toxic to collembolans affecting their reproduction with an $\mathrm{EC}_{50}$ of $0.027 \mathrm{mg}$ a.i. $\mathrm{kg}^{-1} \mathrm{dw}$ soil. Enchytraeids were generally the least sensitive of the three species tested for long-term effects. Earthworms were not always the most sensitive species, emphasizing the need to increase the number of mandatory assays with key non-target organisms in the environmental risk assessment of pesticides.
\end{abstract}

(C) 2014 Elsevier B.V. All rights reserved.

\section{Introduction}

The environmental risk assessment (ERA) of pesticides is based mainly on scenarios developed for northern and central European conditions. This may pose a problem when used for Mediterranean conditions where soil properties, climatic conditions, biological communities, agricultural practices, and crops are substantially different (Daam et al., 2011a; Ramos et al., 2000). These generic scenarios can over- or underestimate the real risks of pesticides when applied to a typical Mediterranean environment (Ramos et al., 2000). Therefore, the use of natural soils is becoming more and more important when performing relevant regional ERA among European regions (Chelinho et al., 2011). Pesticides ERA for

\footnotetext{
* Corresponding author at: Instituto Superior de Agronomia, University of Lisbon, Centro de Eng, Departamento de Ciências e Engenharia de Biossistemas (DCEB), Tapada da Ajuda, 1349-017 Lisboa, Portugal. Tel.: +351213653222.

E-mail addresses: saraleitao@isa.utl.pt, saraleitao@yahoo.com (S. Leitão), mcerejeira@isa.utl.pt (M.J. Cerejeira),Paul.vandenBrink@wur.nl (P.J. Van den Brink), jps@zoo.uc.pt (J.P. Sousa).
}

terrestrial organisms uses standardized ecotoxicological tests traditionally performed in standard artificial soil (e.g., OECD, 1984; ISO, 1998), or in standard natural soil (e.g., LUFA2.2) that often do not possess the characteristics of agricultural natural soils, therefore not mimicking realistic exposure conditions to pesticides for soil biota in the field (Kuperman et al., 2006). It has been documented that differences in soil properties, such as for e.g., organic matter content, may influence pesticide persistence in soil and bioavailability to soil-dwelling organisms (enchytraeids and earthworms) (Amorim et al., 2002a,b; De Silva et al., 2009; Kuperman et al., 2006). Compared to standard artificial soils, natural soils may have properties supporting higher bioavailability of test chemicals; as such their use considerably improves the relevance of laboratory ecotoxicological data for field conditions (Kuperman et al., 2006; Van Gestel et al., 2011). Therefore, the importance of using natural soil is supported by the need to develop more realistic ecotoxicological evaluations for terrestrial ecosystems.

Until the implementation of the new data requirements setup according to the new Pesticide Regulation 1107/2009 (EU, 2013), the protection of terrestrial ecosystems at a first-tier level is assessed in the ERA of pesticides using only the earthworms acute 
test with Eisenia fetida sensu lato (E. fetida and E. andrei) (EC, 2009; SANCO, 2002). Tests using other non-target organisms can be performed if non-target arthropods are believed to be at risk, e.g., tests with Collembola and mites, and on a case-by-case basis depending on the type of the pesticide and its application method (SANCO, 2002). Although earthworms are key species of terrestrial ecosystems as decomposers contributing significantly to organic matter decomposition, nutrient cycling and soil formation (Edwards and Bohlen, 1992; EFSA, 2009a), there is a need for further tests evaluating sub-lethal effects on soil organisms from different trophic levels, taxonomic, physiological and/or functional groups in order to improve the ERA of chemicals in soil (Daam et al., 2011b; EFSA, 2010a; Frampton et al., 2006; Römbke and Moser, 2002). Although there is a growing concern about the potential adverse effects of pesticides in the environment, there is a lack of sub-lethal ecotoxicity data available for non-target terrestrial invertebrates (Daam et al., 2011b; Frampton et al., 2006).

Thus to overcome these limitations, this study aimed to: (i) evaluate sub-lethal effects of pesticides with different types of toxic action (two fungicides and one insecticide) on the reproductive performance of non-target soil invertebrates from different trophic levels: collembolan, enchytraeids, and earthworms; (ii) to increase knowledge on pesticides behavior in the environment (e.g., fate, bioavailability), by using a natural soil from a Mediterranean agricultural area, and (iii) to perform a first-tier risk characterization for the three pesticides by comparing the obtained toxicity data with reported exposure data, whenever possible, elucidating the importance of using natural soil when evaluating exposure and effects on terrestrial organisms.

\section{Material and methods}

\subsection{Pesticide selection, characterization, spiking, and analytical procedures}

Two fungicides, azoxystrobin and chlorothalonil, and the insecticide ethoprophos were chosen after a selection from a list of pesticides authorized on irrigated crops (onion, maize, and potato) in Portugal. A preference was given to insecticides and fungicides with high expected toxicity to soil organisms (Frampton et al., 2006; Wang et al., 2012). The selection was based mainly on ecotoxicity data to terrestrial organisms, namely to earthworms, due to the lack of information on collembolans and enchytraeids. Relevant intrinsic physical and chemical characteristics such as water solubility, capacity to adsorb to soil particles, volatilization, and persistence in soil were also taken into account (Table 1). Information on environmental fate, such as the potential for leaching into groundwater and the predicted environmental distribution (PED) (Table 1), focusing on the soil and water compartments, was assessed using the Groundwater Ubiquity Score and the Mackay fugacity model, respectively (Gustafson, 1989; Mackay, 2001). The application mode (e.g. direct soil application) was also taken in account.

Azoxystrobin (CAS 131860-33-8; methyl (E)-2-\{2-[6- (2cyanophenoxy) pyrimidin-4-yloxy] phenyl $\}-3-$ methoxyacrylate) is a strobilurin fungicide with protectant, curative, eradicant, translaminar, and systemic properties. Its mode of action focuses on inhibiting mitochondrial respiration, spore germination, and mycelial growth and also showing antisporulant activity. It possesses a broad spectrum of activity against the four major groups of fungi: Ascomycota, Oomycota, Deuteromycota, and Basidiomycota (Bartlett et al., 2002; MacBean, 2012). It has been identified as low toxic to birds, mammals, bees, and other non-target terrestrial organisms (arthropods and earthworms) (Bartlett et al., 2002; Gullino et al., 2000).
Table 1

Pesticides physico-chemical characteristics, environmental potential fate (Groundwater Ubiquity Score-GUS and Predicted Environmental Distribution-PED), and pesticides ecotoxicity data for terrestrial earthworm (all data from MacBean, 2012 unless indicated otherwise).

\begin{tabular}{|c|c|c|c|}
\hline & Azoxystrobin & Chlorothalonil & Ethoprophos \\
\hline$S_{\mathrm{w}}\left(\mathrm{mg} \mathrm{L}^{-1}\right)$ & 6.0 & $0.81\left(25^{\circ} \mathrm{C}\right)$ & 700 \\
\hline$K_{\mathrm{ow}}(\log \mathrm{P})$ & $2.5\left(20^{\circ} \mathrm{C}\right)$ & $2.9\left(25^{\circ} \mathrm{C}\right)$ & $3.59\left(21^{\circ} \mathrm{C}\right)$ \\
\hline$K_{\mathrm{oc}}\left(\mathrm{mlg}^{-1}\right)$ & $690^{\mathrm{a}}$ & $850^{\mathrm{d}}$ & $111^{\mathrm{f}}$ \\
\hline $\mathrm{VP}(\mathrm{mPa})$ & $1.10 \mathrm{E}-07$ & $0.076\left(25^{\circ} \mathrm{C}\right)$ & $78^{f}$ \\
\hline $\mathrm{DT}_{50}$ lab soil (d) & $279^{\mathrm{b}}$ & $0.3-87^{d}$ & $10-25^{f}$ \\
\hline $\mathrm{DT}_{50}$ field soil (d) & 14 & $18-70^{\mathrm{d}}$ & $4-25^{g}$ \\
\hline GUS & 2.84 & $\begin{array}{l}2.08\left(\mathrm{DT}_{50} \mathrm{lab}\right. \\
\text { soil } 87)\end{array}$ & $\begin{array}{l}2.73\left(\mathrm{DT}_{50} \mathrm{lab}\right. \\
\text { soil } 25)\end{array}$ \\
\hline \multicolumn{4}{|l|}{ PED (\%) } \\
\hline Soil & 49.5 & 43 & 76.1 \\
\hline Air & 7.39E-08 & 0.285 & 0.122 \\
\hline Aerossol & $8.72 \mathrm{E}-03$ & $2.08 \mathrm{E}-03$ & $5.91 \mathrm{E}-05$ \\
\hline Water & 49.3 & 55.7 & 22.1 \\
\hline Sediment & 1.10 & 0.955 & 1.69 \\
\hline Suspended solids & 0.0344 & 0.0299 & 0.0528 \\
\hline Aquatic biota & $1.23 \mathrm{E}-05$ & $2.43 \mathrm{E}-03$ & 4.29E-03 \\
\hline $\begin{array}{l}\text { Earthworms (lethal } \\
\text { tests) } \mathrm{LC}_{50}(14 \mathrm{~d}) \\
\left(\mathrm{mg} \mathrm{kg}^{-1}\right)\end{array}$ & 283 & $\begin{array}{l}>404 / 268.5 \\
(5 \% \text { OM })^{d}\end{array}$ & $39.6^{\mathrm{f}}$ \\
\hline $\operatorname{NOEC}(14 \mathrm{~d})\left(\mathrm{mg} \mathrm{kg}^{-1}\right)$ & $20^{c}$ & $\begin{array}{l}25(5 \% \text { OM })^{d} \\
1,65(5 \% \\
\text { OM })^{\mathrm{d}, e}\end{array}$ & $<1.67(56 \mathrm{~d})^{\mathrm{f}}$ \\
\hline
\end{tabular}

$S_{\mathrm{w}}$-Solubility in water at $20^{\circ} \mathrm{C} ; K_{\mathrm{ow}}-$ Octanol-water partition coefficient at $\mathrm{pH} 7$; $K_{\text {oc }}$-Organic carbon sorption constant; VP-Vapor pressure at $20^{\circ} \mathrm{C}$; DT50-Half life in soil at $20^{\circ} \mathrm{C}$ under aerobic conditions; GUS $=\log ($ DT50 $) \times\left(4-\log \left(K_{\text {oc }}\right)\right)-$ GUS $>2.8$ : leacher; $1.8<$ GUS < 2.8: transition; GUS < 1.8: improbable leacher (Gustafson, 1989); PED-Predicted Environmental Distribution according to Mackay (2001)-Mackay fugacity model ('level I, version 3.00, 2004, Trentu University, Canada') PED < 20\%: very low affinity; $20 \% \leq$ PED < 40\%: low affinity; $40 \% \leq$ PED < $60 \%$ : average affinity; $60 \% \leq \mathrm{PED}<80 \%$ : high affinity; $\mathrm{PED} \geq 80 \%$ : very high affinity; OM-organic matter.

a EFSA (2010b), value for sandy clay loam soil.

b EC (1998), average value resulting from different soils.

c FOOTPRINT (2012).

d EC (2006).

e EC (2006), test with chlorothalonil $500 \mathrm{~g} \mathrm{~L}^{-1} \mathrm{SC}$.

f $\operatorname{EFSA}$ (2006).

g EFSA (2006), representative range for southern and central Europe locations.

Chlorothalonil (CAS 1897-45-6; tetrachloroisophthalonitrile) is a chloronitrile fungicide with a non-systemic broad-spectrum mode of action and foliar action with some protectant properties. It is a broad spectrum organochlorine fungicide effective against fungal diseases like potato late blight agent and fungus Phytophthora infestans (Mont.) de Bary and Alternaria solani (Ellis \& G. Martin) L.R. Jones \& Grout. Chlorothalonil acts also by preventing spore germination and zoospore motility (Sakkas et al., 2002; MacBean, 2012). Although effects on earthworms have been registered (Potter et al., 1994; Tu et al., 2011), information on other non-target organisms is scarce.

Ethoprophos (CAS 13194-48-4; O-ethyl S,S-dipropyl phosphorodithioate) is a broad spectrum organophosphate insecticide and nematicide with moderate residual activity and is not phytotoxic. It is an acetylcholinesterase inhibitor and is a non-systemic nematicide and soil insecticide with contact action. Ethoprophos is effective against potato nematodes (Globodera rostochiensis (Wollenweber) Behrens, G. pallide (Stone) Behrens) and soil insects (Agriotes spp., Agrotis spp. and Melolontha spp.) on maize crop (Karpouzas et al., 1999a,b; MacBean, 2012). Effects on non-target soil organisms are scarce and the information available is related to artificial soil (EFSA, 2006; Sánchez-Moreno et al., 2009), although effects on terrestrial arthropods may be expected due to the pesticide type of toxic action (Frampton et al., 2006). Adverse effects on the abundance and biomass of earthworms are known (reduction of $88-95 \%$ and $83-96 \%$, respectively, 3 weeks after the application of $5.6 \mathrm{~kg}$ a.i. ha ${ }^{-1}$ of Mocap10G in turf soil) (Potter et al., 1994). 
In order to evaluate the environmental impact of the pesticides under realistic application in the agricultural fields, azoxystrobin, and chlorothalonil were tested as the concentrated suspension formulation ORTIVA ${ }^{\circledR}\left(250 \mathrm{ga.i}^{-1}\right)$ and BRAVO $500^{\circledR}\left(500 \mathrm{~g}^{\text {a.i. }} \mathrm{L}^{-1}\right)$, respectively. Ethoprophos was tested as pure compound (Dr. Ehrenstorfer $93.0 \%$ purity) because the available formulation in Portugal (MOCAP $10 \mathrm{G}^{\circledR}$ ) consists of microgranules which poses a limitation in terms of nominal concentration calculation since it remains active in soil against insects for 2-4 months. For spiking procedures, specific amounts of the aqueous solution of each pesticide were prepared with distilled water to attain a moisture content of the natural soil of $50 \%$ of the water-holding capacity (WHC). No solvents were used due to the fungicides formulations, and the insecticide active ingredient, high solubility in water. The soils were spiked on day one of the start of the experiments and the aqueous solutions used for spiking the soil were stored in refrigerated conditions $\left(4-6^{\circ} \mathrm{C}\right)$ until pesticide residue analysis. Azoxystrobin and chlorothalonil residues in water were analyzed by an independent laboratory, through solid phase extraction followed by gas chromatography/mass spectrometry (SPE/GC-MS) and ethoprophos residues through by liquid chromatography/mass spectrometry/mass spectrometry (LC-MS/MS) according to DIN 38407-F 2 (1993) and ISO 10695 (2000). Limits of quantification (LOQ) were $0.1 \mu \mathrm{g} \mathrm{ml}^{-1}$ for azoxystrobin, $0.3 \mu \mathrm{g} \mathrm{ml}^{-1}$ for chlorothalonil and $0.05 \mu \mathrm{g} \mathrm{L}^{-1}$ for ethoprophos.

\subsection{Test organisms and culture conditions}

Three different soil organisms were used: springtails Folsomia candida (Willem, 1902) (Collembola: Isotomidae), the potworm Enchytraeus crypticus (Westheide \& Graefe, 1992) (Oligochaeta: Enchytraeidae) and the earthworms Eisenia andrei (Bouché, 1972) (Oligochaeta: Lumbricidae). All test organisms used in the experiments originated from laboratory cultures maintained at a constant temperature of $20 \pm 2{ }^{\circ} \mathrm{C}$ with a photoperiod of $16: 8 \mathrm{~h}$ light:dark. Springtails were cultured in plastic vessels lined with an 11:1 mixture of plaster and activated charcoal. A small amount of granulated dry yeast was added as a food source once a week to avoid spoilage by fungi and moldy food was removed when detected. The organisms were synchronized to be 10-12 days old at the start of the test. The Enchytraeid E. crypticus is listed in the ISO protocol 16387 (2004) as an alternative to E. albidus and was chosen for this study due to its better performance on natural soils with $\mathrm{pH}$, organic matter content (OM), and clay characteristics similar to the test soil. It is also the preferred species when assessment objectives include natural soil types that support higher bioavailability of chemicals (Kuperman et al., 2006). The enchytraeids were cultured in aerated plastic vessels using uncontaminated garden soil that was defaunated before use by deep-freezing cycles and with no additives as compost of fertilizers and pesticides. The soil was moistened at $50 \%$ WHC and verified weekly to maintain its moisture content. The test organisms were fed weekly with finely ground dry oat placed under soil particles to prevent fungal growth and facilitate availability of food to small juveniles (Römbke and Moser, 2002). The organisms used in the tests were carefully removed from the soil with the help of tweezers and placed on petri dishes with distilled water for selection under a stereomicroscope, as possessing clitella and a body size between $10 \mathrm{~mm}$ and $12 \mathrm{~mm}$ long. Before the performance of the experiments the natural test soil was checked for its suitability by observing the response behavior of a group of organisms for a period of more than 2 weeks (Römbke and Moser, 2002). Earthworms were kept in aerated plastic vessels with a mixture of horse manure and peat as substrate. This mixture was moistened periodically to maintain the moisture content between $40 \%$ and $60 \%$ of the WHC. The test organisms were fed twice a month with oat porridge. The earthworms used in the tests were synchronized to be more than one month old and before the start of the experiments the adults with clitella were separated and acclimated to the uncontaminated test substrate (natural soil and OECD 10\% OM) for a period of between $24 \mathrm{~h}$ and $48 \mathrm{~h}$. No mortality was observed during acclimation. After that, each organism was cleaned in water to remove soil particles, gently dried on absorbent paper, weighted (250-600 mg) and placed into plastic vessels covered with a lid in groups of ten.

\subsection{Test soils}

Artificial OECD soil with $10 \%$ organic matter content was prepared following the guideline instructions (OECD, 1984) and soil $\mathrm{pH}$ was adjusted to $6.0 \pm 0.5$ with $\mathrm{CaCO}_{3}$. The natural soil used in this study, a eutric cambisol (EuDASM, 2011), is from an uncontaminated non-cultivated local from an important agricultural area in Ribatejo, Central Portugal. The uppermost soil layer (top 15-20 cm) was taken from the field, air dried, and sieved through a $2 \mathrm{~mm}$ mesh and submitted to several deep-freezing $\left(-20^{\circ} \mathrm{C}\right)$ cycles to eliminate any existing fauna, and preserved at $4-6^{\circ} \mathrm{C}$ until used in the ecotoxicological tests. The soil was also tested for pesticide residues using a multi method ASU L 00.00-34 GC detection analyses (ASU L, 1999). Soil parameters measured in the laboratory were soil $\mathrm{pH}(1 \mathrm{M} \mathrm{KCl})$, moisture content and water-holding capacity. Organic matter content, soil particle size distribution, cation exchange capacity, total elements, and other chemical and physical characteristics were assessed by international and internal laboratorial standard methodologies. The characteristics of the natural soil and methodologies used are summarized in Table 2. Both soils were moistened to $50 \%$ of the water-holding capacity immediately before the start of the tests.

\subsection{Experimental design of terrestrial ecotoxicity tests}

All test treatments were performed with natural soil and two control soil types were used, one with natural soil for results comparison and other with OECD artificial soil for organism's performance validation. The ecotoxicological tests were performed under a controlled temperature of $20^{\circ} \mathrm{C} \pm 2{ }^{\circ} \mathrm{C}$ with a light:dark cycle of $16 \mathrm{~h}: 8 \mathrm{~h}$.

\subsubsection{Collembolan reproduction test}

Chronic toxicity tests followed ISO (1999) procedures. The following gradients of concentrations were selected to assess the full dose-response relationships for each pesticide: azoxystrobin (10, $15,20,35,50,80,120,200,300,450,650$, and $1000 \mathrm{mg}$ a.i. $\mathrm{kg}^{-1}$ dw soil); chlorothalonil $(0.5,1,1.5,2.5,5,10,20,30,50,80,150$, and $200 \mathrm{mg}$ a.i. $\mathrm{kg}^{-1} \mathrm{dw}$ soil) and ethoprophos $(0.015,0.020,0.030$, 0.040 , and $0.050 \mathrm{mg}$ a.i. $\mathrm{kg}^{-1} \mathrm{dw}$ soil). The 28 days reproduction toxicity tests consisted of 10 synchronized springtails of 10-12 days old exposed to $30 \mathrm{~g}$ fresh weight soil per glass vessel, and fed with $2 \mathrm{mg}$ of dry yeast at the start of the experiment. To reduce evaporation and prevent springtails from escaping, the vessels were closed with a lid with small holes to allow aeration. Two replicates were used per test concentration and not the standard four replicates due to the high number of concentrations adopted in order to increase the robustness of the test and $\mathrm{EC}_{50}$ calculations. Four replicates were used for each of the control soils as well as for the analysis of ethoprophos due to the number of concentrations tested. An extra vessel without test organisms and food was prepared for each combination and used for $\mathrm{pH}(1 \mathrm{M} \mathrm{KCl})$ and moisture determination at the end of the test (ISO, 1994, ISO, 1999). All replicates were aerated twice a week, and 14 days after the start of the test 2 mg of granulated dry yeast were added and moisture loss replenished if needed, according to total initial vessel weights. After 4 weeks, juveniles were assessed by flooding the vessels with water, by adding a few 
Table 2

Natural soil properties and respective analytical methods.

\begin{tabular}{|c|c|c|c|c|c|}
\hline & Natural soil & Methods & & Natural soil & Methods \\
\hline Particle size distribution & & $\begin{array}{l}\text { Hydrometer of } \\
\text { Boyoucos, IM }\end{array}$ & OM content (\%) & 5.74 & $\begin{array}{l}\text { Dry combustion ISO } \\
10694,1995\end{array}$ \\
\hline Sand (\%) & 54.4 & - & Chemical parameters & & - \\
\hline Silt (\%) & 22.1 & - & $\mathrm{P}_{2} \mathrm{O}_{5}\left(\mathrm{mg} \mathrm{kg}^{-1}\right)$ & 99 & $\begin{array}{l}\text { Egner-Rhiem ICP-OES, } \\
\text { IM }\end{array}$ \\
\hline Clay (\%) & 23.5 & - & $\mathrm{K}_{2} \mathrm{O}\left(\mathrm{mg} \mathrm{kg}^{-1}\right)$ & $>200$ & - \\
\hline Soil texture & Sandy clay loam & & $\mathrm{Mg}\left(\mathrm{mg} \mathrm{kg}^{-1}\right)$ & $>125$ & $\begin{array}{l}\text { Ammonium acetate } \\
1 \mathrm{M} \mathrm{pH} 7 \text { FAAS, IM }\end{array}$ \\
\hline $\mathrm{pH}\left(\mathrm{H}_{2} \mathrm{O}\right)$ & 5.9 & $\begin{array}{l}\text { Potentiometry } \\
\left(20 \pm 2^{\circ} \text { C) IM, }\right. \\
\text { LAS.PL.20.V01, } 2009\end{array}$ & $\mathrm{CaCO}_{3}(\%)$ & 0 & ISO 10693,1995 \\
\hline $\mathrm{pH}(1 \mathrm{M} \mathrm{KCl})$ & 5.0 & ISO $10390(1994)$ & $\mathrm{Fe}\left(\mathrm{mg} \mathrm{kg}^{-1}\right)$ & $>80$ & $\begin{array}{l}\text { AAAc - EDTA } \\
\text { (Lakanen)/FAAS, IM }\end{array}$ \\
\hline Moisture (\%) & 11 & ISO 11268-2.2 (1998) & $\operatorname{Mn}\left(\mathrm{mg} \mathrm{kg}^{-1}\right)$ & 38 & - \\
\hline WHC max (\% dry weight) & 54.4 & ISO $11268-2.2(1998)$ & $\mathrm{Zn}\left(\mathrm{mg} \mathrm{kg}^{-1}\right)$ & 1.8 & - \\
\hline Cation exchange capacity (me/100 g) & 9.12 & $\begin{array}{l}\text { ammonium acetate } \\
1 \mathrm{M} \mathrm{pH} 7 \text { FAAS }\end{array}$ & $\mathrm{Cu}\left(\mathrm{mg} \mathrm{kg}^{-1}\right)$ & 3 & - \\
\hline Sum of base exchange (me/100 g) & 6.72 & $\begin{array}{l}\text { ( } \mathrm{Ca} \text { and } \mathrm{Mg} \text { ) and FAES } \\
(\mathrm{K} \text { and } \mathrm{Na} \text { ) Titration IM }\end{array}$ & $\mathrm{B}\left(\mathrm{mg} \mathrm{kg}^{-1}\right)$ & 0.69 & $\begin{array}{l}\text { Boiling water/ICP-OES, } \\
\text { IM }\end{array}$ \\
\hline Degree of base saturation (\%) & 73.7 & - & $\mathrm{N}(\%)$ & 0.297 & $\begin{array}{l}\text { Dry combustion ISO } \\
13878,1998\end{array}$ \\
\hline
\end{tabular}

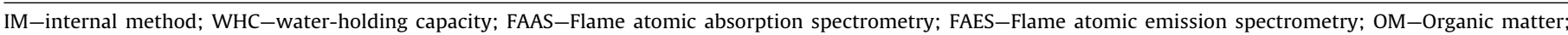
ICP-OES-Inductively coupled plasma optical emission spectrometry.

drops of ink and gentle stirring, after which the animals floating on the water surface were photographed and counted using the Image Tool software (Wilcox et al., 2002). The endpoint of the test was the total number of juveniles per test vessel at the end of the test; adult numbers were also registered.

\subsubsection{Enchytraeids reproduction test}

The reproduction tests were performed based on ISO 16387 (2004) guidelines with a few modifications. The test duration was 4 weeks instead of the 6 weeks indicated in ISO 16387 for the E. albidus, to accommodate the shorter reproductive cycle of $E$. crypticus (Kuperman et al., 2004). To assess the full dose-response relationships, concentrations series of azoxystrobin $(10,15,20$, $35,50,80,120,200,300,450,650,1000 \mathrm{mg}^{2} .1 . \mathrm{kg}^{-1} \mathrm{dw}$ soil), chlorothalonil $(5,10,20,30,40,60,90,150,200,250,300$, and $500 \mathrm{mga.i.} \mathrm{kg}^{-1} \mathrm{dw}$ soil) and ethoprophos (20, 30, 45, 65, and $100 \mathrm{mg}$ a.i. $\mathrm{kg}^{-1} \mathrm{dw}$ soil) were selected. The test started with the introduction of ten adult enchytraeids with well developed clitella in glass test vessels, each containing approximately $20 \mathrm{~g}$ of dw soil and $50 \mathrm{mg}$ of finely ground dry oats of food covered with soil particles. Two replicates per pesticide treatment were used and not the standard four replicates due to the high number of concentrations adopted in order to increase the robustness of the test and $\mathrm{EC}_{50}$ calculations. Four replicates were used for each of the control soils tested. An extra vessel without test organisms and food was prepared for each treatment concentration and used for $\mathrm{pH}(1 \mathrm{M}$ $\mathrm{KCl}$ ) and moisture determination at the end of the test (ISO 10390, 1994; ISO 16387, 2004). All replicas were weighed weekly for moisture loss replenishment and $25 \mathrm{mg}$ of food added if needed. At the end of the test all enchytraeids in soil (adults and juveniles) were collected by transferring all test vessels content to a metal sieve $(500 \mu \mathrm{m})$ placed in a bowl and filled with water so that the soil was submerged under the water. The organisms tended to stay at the surface of the soil and water and were collected with a plastic pipette. Each replicate group of organisms was fixed with alcohol and stained with Bengal red before counting. The measurement endpoint was the number of juveniles at the end of the test.

\subsubsection{Earthworm reproduction test}

The ecotoxicity tests followed the ISO 11268-2.2 (1998) guidelines. The following gradients of concentrations were selected to assess the full dose-response relationships for each pesticide:

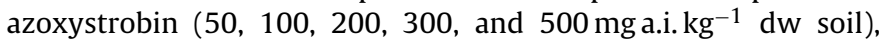
chlorothalonil $\left(5,10,20,50\right.$, and $100 \mathrm{mga.i}^{-1} \mathrm{~kg}^{-1} \mathrm{dw}$ soil) and ethoprophos $\left(0.1,0.3,1,3\right.$, and $12 \mathrm{mg}^{2}$ a.i. $\mathrm{kg}^{-1} \mathrm{dw}$ soil). Four replicates were used per test concentration and for each of the control soils tested. At the beginning of the test, cylindrical plastic vessels $(500 \mathrm{ml})$ with perforated transparent lids to facilitate air circulation were filled with $500 \mathrm{~g}$ dw soil. Fifteen grams of moistened dry finely ground horse manure were added to each test vessel and ten earthworms, previously weighted, were placed on each of the test replicates. The groups of ten test organisms were paired randomly with each replicate and each group was weighted. The test vessels were weighed for weekly moisture loss and replenished if needed. After 4 weeks of exposure, living adults were removed by hand sorting and each replicate's living test organisms weighed for biomass determination. Mortality of adult individuals was assessed by counting the living organisms and any individuals not accounted for were considered dead. The soil and existing cocoons returned to the test vessels and $5 \mathrm{~g}$ of food added, and incubated for another 4 weeks to allow cocoon development. At the end of the test, juveniles were extracted from the test soil using a water bath kept at $50 / 60^{\circ} \mathrm{C}$ and counted. The test endpoints were adult mortality and change of biomass after 4 weeks and number of juveniles produced after 8 weeks. Soil $\mathrm{pH}(1 \mathrm{M} \mathrm{KCl})$ and moisture were determined at the beginning and at the end of the experiment for each concentration tested (ISO 10390, 1994; ISO 11268-2.2, 1998).

\subsection{Calculations and statistical analyzes}

Results were statistically analyzed according to EPS 1/RM/46 (2005) and using STATISTICA 7.0 (Stat Soft Inc, 2004).

Effect concentrations of $50 \%$ and $20 \%$ in reproduction tests and corresponding 95\% confidence limits were calculated through concentration-response relationships using nonlinear regressions. The nonlinear regression model was selected in order to best describe the concentration-response trend with the help of scatter plots or line graphs for each experiment distribution and the proportion of variance accounted for $\left(r^{2}\right)$. Model used was: (i) logistic: juveniles $=t /\left(1+(\operatorname{conc} / x)^{\wedge} b\right)$ where: $t-y$-intercept (control response); $x$-estimated EC value for the data set; $b$-a scale parameter (EPS 1/RM/46, 2005), with the estimation method of Levenberg-Marquardt. For the estimation of the $\mathrm{EC}_{x}$ values, the 
Table 3

Average number of juveniles ( \pm standard deviation) in the controls $(n=4)$ at the end of the terrestrial ecotoxicity tests conducted with the different soil organisms using natural and artificial soil.

\begin{tabular}{llrr}
\hline Organism tested & Pesticide tested & \multicolumn{1}{c}{$\begin{array}{l}\text { Natural soil } \\
\text { (sandy loam) }\end{array}$} & $\begin{array}{r}\text { Artificial soil } \\
\text { (OECD 10\%) }\end{array}$ \\
\hline Collembolans & Azoxystrobin & $262 \pm 79$ & $250 \pm 23$ \\
& Chlorothalonil & $414 \pm 29$ & $130 \pm 27$ \\
& Ethoprophos & $317 \pm 47$ & $184 \pm 53$ \\
Enchytraeids & Azoxystrobin & $1204 \pm 70$ & $442 \pm 163$ \\
& Chlorothalonil & $1321 \pm 143$ & $729 \pm 92$ \\
Earthworms & Ethoprophos & $1373 \pm 543$ & $1200 \pm 100$ \\
& Azoxystrobin & $77 \pm 3$ & $36 \pm 7$ \\
& Chlorothalonil & $80 \pm 11$ & $34 \pm 5$ \\
& Ethoprophos & $75 \pm 10$ & $34 \pm 5$ \\
\hline
\end{tabular}

normality for all test results was evaluated through a Q-Q plot of the residuals. The homogeneity of the variance was also evaluated after the analysis through a graphical distribution of the predicted versus the residual values.

On those tests where 4 replicates were used (Collembola tests with ethoprophos and Earthworms with all pesticides), NOEC (no observed effect concentration) and LOEC lowest observed effect concentration) values were estimated using a one way analysis of variance (ANOVA) followed by a Dunnett test. In this case normality of the distribution and homogeneity of the variance were tested using Kolmogorov-Smirnov (K-S) and Levene's tests, respectively. The same statistical procedure was performed to evaluate significant differences in earthworm mortality and biomass variations among chemical treatments and respective controls.

\section{Results}

\subsection{Test soils}

No pesticide residues were detected in the natural soil test which validates its use as a test soil for this study. The validity criteria of controls for each single species reproduction test were attained (collembolans: mortality of adults $<20 \%$; reproduction rate of $>100$ instars per vessel; coefficient of variation of reproduction $<30 \%$; enchytraeids: mortality of adults $<20 \%$; reproduction rate of $>25$ juveniles per vessel; coefficient of variation of reproduction $<50 \%$; and earthworms: mortality of adults $\leq 10 \%$; reproduction rate of $\geq 30$ juveniles per vessel; coefficient of variation of reproduction $<30 \%$ ). The $\mathrm{pH}$ and moisture content in the natural soil controls of the three terrestrial ecotoxicity tests were on average $4.71 \%$ and $20 \%$ at the start of the tests respectively, and increased by an average of 0.1 units and $0.11 \%$, respectively, at the end of the test. Artificial control soil average $\mathrm{pH}$ decreased 0.1 units from the initial values of 5.63, and moisture content decreased $0.42 \%$ from the initial value of $29 \%$. Generally the three test organisms reproduced twice as much in the natural soil control compared to the OECD artificial soil control (Table 3 ).

\subsection{Exposure concentrations}

The measured concentrations in the stock solutions of azoxystrobin and chlorothalonil were on average $97.8 \%$ and $93.5 \%$, respectively, of those of the nominal stock solutions used for spiking the soil on the terrestrial tests. Since the nominal and measured concentrations did not differ substantially, no adjustments for recovery were made when calculating the toxicity endpoints. Ethoprophos concentration could not be measured due to laboratory technical difficulties but since identical work procedures were used, the risk of erroneous dosage in the present study was deemed

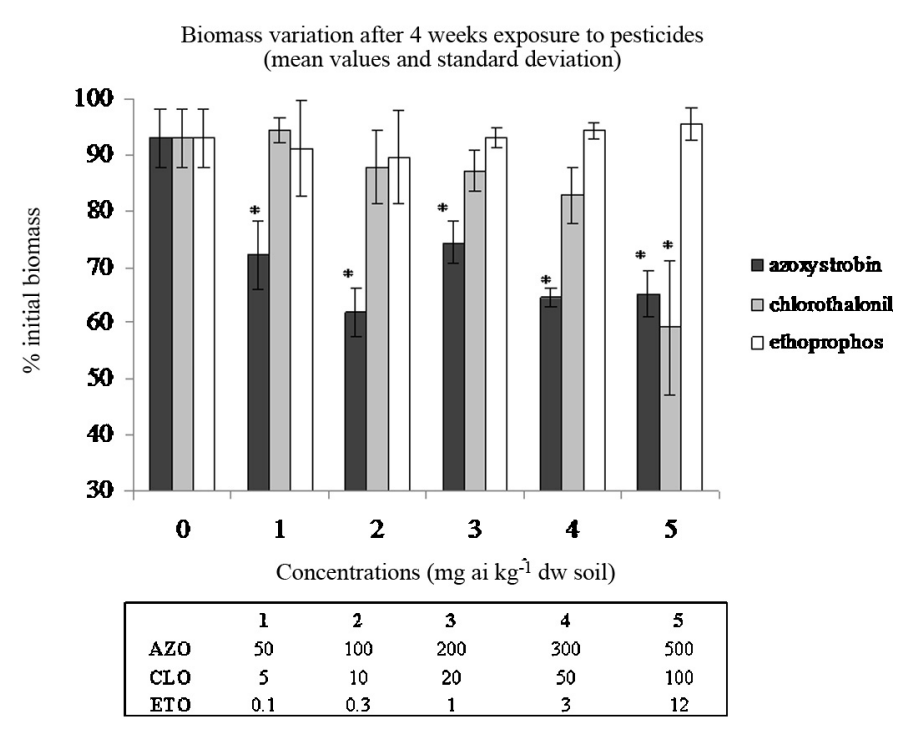

Fig. 1. Adult earthworm (Eisenia andrei) biomass variation after 4 weeks exposure to the tested pesticides (mean $\pm S D)$. ${ }^{*}$ Significant differences with control $(p<0.05)$

minimal and the nominal concentrations were used for the toxicity endpoint assessment.

\subsection{Assessment of pesticides effects to terrestrial organisms}

In order to account for the differences in mass of each pesticide when comparing the results for the same organism between the pesticides, the active ingredient individual molar mass was used to transform the results values into mol of active ingredient (a.i.) per $\mathrm{kg}$ of dry weight of soil. This is the reason why results are shown in two types of units ('mg a.i. $\mathrm{kg}^{-1} \mathrm{dw}$ soil' and 'mol a.i. $\mathrm{kg}^{-1} \mathrm{dw}$ soil') in the text and Table 4.

\subsubsection{Collembolans}

Adult collembolans showed a maximum of $10 \%$ mortality at the higher concentration (1000 mga.i. $\mathrm{kg}^{-1} \mathrm{dw}$ soil) during the reproduction tests with azoxystrobin. The highest chlorothalonil exposure concentration resulted in 35\% mortality effect on adult collembolans after 4 weeks of exposure $\left(150 \mathrm{mga}\right.$ a.i. $\mathrm{kg}^{-1} \mathrm{dw}$ soil). No adult collembolans were observed at the two highest ethoprophos concentrations $\left(0.040\right.$ and $0.050 \mathrm{mg}$ a.i. $\mathrm{kg}^{-1} \mathrm{dw}$ soil) and a $65 \%$ mortality rate was found at $0.030 \mathrm{mg}$ a.i. $\mathrm{kg}^{-1}$ dw soil. Ethoprofos had a significant effect on the reduction of juveniles at much lower concentrations $(1000 \times$ less $)$ compared to azoxystrobin and chlorothalonil test (Table 4), with an $\mathrm{EC}_{50}$ of $1.11 \times 10^{-7} \mathrm{mola}$ a. $\mathrm{kg}^{-1} \mathrm{dw}$ soil. The $\mathrm{EC}_{50}$ of azoxystrobin (in mola.i. $\mathrm{kg}^{-1} \mathrm{dw}$ soil) was two times higher than that of chlorothalonil, herewith showing azoxystrobin to be less toxic for collembolans.

\subsubsection{Enchytraeids}

Enchytraeids were affected by the three chemicals at comparable concentrations (Table 4), with the $\mathrm{EC}_{50}$ values of 2.46 and $2.83 \times 10^{-4}$ mol a.i. $\mathrm{kg}^{-1} \mathrm{dw}$ soil for azoxystrobin and ethoprophos, respectively, which is approximately half of the chlorothalonil value of $4.25 \times 10^{-4} \mathrm{~mol}$ a.i. $\mathrm{kg}^{-1} \mathrm{dw}$ soil (Table 4 ).

\subsubsection{Earthworms}

The biomass of adult earthworms exposed to the control with natural soil for 4 weeks showed an average decrease of $7.0 \%$ compared to the initial biomass (Fig. 1). The exposure of $E$. andrei to azoxystrobin resulted in a significant weight 
Table 4

Pesticides molecular mass and results of statistical analysis for sub-lethal effects on terrestrial organism reproduction for each pesticide.

\begin{tabular}{|c|c|c|c|c|c|c|}
\hline $\begin{array}{l}\text { Pesticide Mol } \\
\text { mass }\left(\mathrm{g} \mathrm{mol}^{-1}\right)\end{array}$ & Organism & $\mathrm{EC}_{x}(95 \% \mathrm{CI})\left(\mathrm{mg}\right.$ a.i. $\mathrm{kg}^{-1} \mathrm{dw}$ soil $)$ & $\mathrm{EC}_{x}$ (mola.i. $\mathrm{kg}^{-1}$ dw soil) & Model $r^{2}$ & $\begin{array}{l}\text { NOEC-LOEC } \\
\left(\mathrm{mg}^{2} \text { a.i. } \mathrm{kg}^{-1} \mathrm{dw} \text { soil }\right)\end{array}$ & Normality homogeneity \\
\hline \multirow{2}{*}{ AZO } & \multirow{2}{*}{ Folsomia candida } & $\mathrm{EC}_{50}=92.0(57.9-126.1)$ & $\mathrm{EC}_{50}=2.28 \times 10^{-4}$ & 0.88 & - & - \\
\hline & & $\mathrm{EC}_{20}=54.9(23.0-86.9)$ & $\mathrm{EC}_{20}=1.36 \times 10^{-4}$ & - & - & - \\
\hline \multirow{4}{*}{$(403.4)$} & \multirow{2}{*}{ Enchytraeus crypticus } & $\mathrm{EC}_{50}=99.2(73.3-125.7)$ & $\mathrm{EC}_{50}=2.46 \times 10^{-4}$ & 0.95 & - & - \\
\hline & & $\mathrm{EC}_{20}=42.6(25.2-60.0)$ & $\mathrm{EC}_{20}=1.06 \times 10^{-4}$ & - & - & - \\
\hline & \multirow{2}{*}{ Eisenia andrei } & $\mathrm{EC}_{50}=42.0(23.2-60.8)$ & $\mathrm{EC}_{50}=1.04 \times 10^{-4}$ & 0.96 & $<50$ & $\mathrm{~K}-\mathrm{S} p>0.20$ \\
\hline & & $\mathrm{EC}_{20}=12.2(1.2-23.1)$ & $\mathrm{EC}_{20}=3.02 \times 10^{-5}$ & - & 50 & Levene's $p=0.07$ \\
\hline \multirow{2}{*}{ CLO } & \multirow{2}{*}{ Folsomia candida } & $\mathrm{EC}_{50}=31.1(24.7-37.5)$ & $\mathrm{EC}_{50}=1.17 \times 10^{-4}$ & 0.95 & - & - \\
\hline & & $\mathrm{EC}_{20}=18.2(12.0-24.5)$ & $\mathrm{EC}_{20}=6.84 \times 10^{-5}$ & - & - & - \\
\hline \multirow{4}{*}{$(265.9)$} & \multirow{2}{*}{ Enchytraeus crypticus } & $\mathrm{EC}_{50}=112.9(89.8-136.1)$ & $\mathrm{EC}_{50}=4.25 \times 10^{-4}$ & 0.955 & - & - \\
\hline & & $\mathrm{EC}_{20}=39.4(25.6-53.3)$ & $\mathrm{EC}_{20}=1.48 \times 10^{-4}$ & - & - & - \\
\hline & \multirow{2}{*}{ Eisenia andrei } & $\mathrm{EC}_{50}=40.9(30.1-51.7)$ & $\mathrm{EC}_{50}=1.54 \times 10^{-4}$ & 0.94 & 5 & $\mathrm{~K}-\mathrm{S} p>0.20$ \\
\hline & & $\mathrm{EC}_{20}=20.8(11.0-30.5)$ & $\mathrm{EC}_{20}=7.82 \times 10^{-5}$ & - & 10 & Levene's $p=0.09$ \\
\hline \multirow{2}{*}{ ETO } & \multirow{2}{*}{ Folsomia candida } & $\mathrm{EC}_{50}=0.027(0.024-0.031)$ & $\mathrm{EC}_{50}=1.11 \times 10^{-7}$ & 0.944 & 0.020 & $\mathrm{~K}-\mathrm{S} p>0.10$ \\
\hline & & $\mathrm{EC}_{20}=0.021(0.017-0.026)$ & $\mathrm{EC}_{20}=8.67 \times 10^{-8}$ & - & 0.030 & Cochran $C p=1.00$ \\
\hline \multirow{4}{*}{$(242.3)$} & \multirow{2}{*}{ Enchytraeus crypticus } & $\mathrm{EC}_{50}=68.5(42.9-94.1)$ & $\mathrm{EC}_{50}=2.83 \times 10^{-4}$ & 0.77 & - & - \\
\hline & & $\mathrm{EC}_{20}=41.2(17.2-65.2)$ & $\mathrm{EC}_{20}=1.70 \times 10^{-4}$ & - & - & - \\
\hline & \multirow{2}{*}{ Eisenia andrei } & $\mathrm{EC}_{50}=8.3(3.6-13.0)$ & $\mathrm{EC}_{50}=3.43 \times 10^{-5}$ & 0.76 & 3 & $\mathrm{~K}-\mathrm{S} p>0.20$ \\
\hline & & $\mathrm{EC}_{20}=3.5(0-7.1)$ & $\mathrm{EC}_{20}=1.44 \times 10^{-5}$ & - & 12 & Levene's $p=0.12$ \\
\hline
\end{tabular}

Mol mass-molecular mass (MacBean, 2012); AZO-azoxystrobin, CLO-chlorothalonil, ETO-ethoprophos; CI-Confidence interval; $p-$ probability value.

loss (Dunnett test $p<0.05$ ) throughout the concentration gradient (Fig. 1). A 7.7\% adult mortality was observed only at the higher concentration ( $\mathrm{LC}_{50}>500 \mathrm{mg}$ a.i. $\mathrm{kg}^{-1} \mathrm{dw}$ soil). Exposure to chlorothalonil resulted in a weight loss gradient (5.5-40.9\%) with increasing pesticide concentration (Fig. 1) with only significant values for the highest concentration of $100 \mathrm{mga}$ a. $\mathrm{kg}^{-1}$ $\mathrm{dw}$ soil. This biomass decrease was accompanied by a mortality rate of $59.0 \%$ only at the highest concentration resulting in a $\mathrm{LC}_{50}$ for adults of approximately $95.0 \mathrm{mg}$ a.i. $\mathrm{kg}^{-1} \mathrm{dw}$ soil. No adult earthworm mortality was observed after 4 weeks exposure to ethoprophos ( $\mathrm{LC}_{50}>12 \mathrm{mg}$ a.i. $\mathrm{kg}^{-1} \mathrm{dw}$ soil), and a slight (but not significant) gain of weight was determined (91.1 to $95.5 \%$ of initial biomass) along the concentration gradient (Fig. 1). The highest toxicity on earthworms' reproduction was found for ethoprophos resulting in an $\mathrm{EC}_{50}$ of $3.43 \times 10^{-5} \mathrm{mola}$ a. $\mathrm{kg}^{-1} \mathrm{dw}$ soil (Table 4). The inhibition of juvenile production by earthworms under azoxystrobin and chlorothalonil exposure resulted in similar $\mathrm{EC}_{50}$ toxicity values $\left(1.04 \times 10^{-4} \mathrm{~mol}\right.$ and $1.54 \times 10^{-4} \mathrm{~mol}$ a.i. $\mathrm{kg}^{-1}$ $\mathrm{dw}$ soil, respectively). Nevertheless, $\mathrm{EC}_{20}$ values differed between these pesticides with azoxystrobin being more toxic (Table 4). A significant reduction in juvenile numbers (Dunnett test $p<0.05$ ) was observed for all the three pesticides allowing LOEC and NOEC calculations (Table 4). However, in azoxystrobin all tested concentrations were significantly different from the control $(p<0.005)$ resulting in effects on earthworms, which did not allow for a NOEC value to be attained (NOEC $<50 \mathrm{mg}$ a.i. $\mathrm{kg}^{-1} \mathrm{dw}$ soil).

\section{Discussion}

The study focused on evaluating the effects on the reproduction of non-target soil organisms for three commonly used pesticides in irrigated crops using a Mediterranean natural soil. All the test organisms presented different toxicity responses to the tested pesticides (Table 4). This could be associated with the processes of chemical uptake by the organisms and the different types of toxic action of the pesticides (Frampton et al., 2006). Uptake of organic contaminants by terrestrial organisms is intimately associated with the soil pore water which is in general the dominant pathway (EFSA, 2009b; Styrishave et al., 2008). Soft bodied soil organisms such earthworms and enchytraeids take pesticides up either through passive diffusion from pore water through the skin or by ingestion together with soil particles (De Silva et al., 2009). Hard-bodied soil organisms as collembolans take oxygen and water through specialized organs also from the soil pore water (EFSA, 2009b). In addition, pesticides bioavailability through the soil pore water can be influenced by soil properties such as organic matter $(\mathrm{OM})$ and clay content (increase of $\mathrm{OM}$ and clay) that relates to sorption restraining the pesticide molecules in a form that is not available for organism uptake (EFSA, 2009b; Kuperman et al., 2006; Van Gestel, 2012). This fact has been reported by several authors for soil-dwelling organisms such as enchytraeids and earthworms, for a number of compounds: organochlorine and carbamate insecticides, benzimidazole, and polychlorinated fungicides, among others (Amorim et al., 2002a,b; De Silva et al., 2009; Lanno et al., 2004; EFSA, 2009a; Patakioutas and Albanis, 2002).

\subsection{Effects of azoxystrobin on soil biota}

In spite of the low solubility of azoxystrobin in water as active ingredient (Table 1), its partition to the soil pore water may be expected due to its formulation product being water soluble as concentrated suspension. Azoxystrobin is expected to have low environmental toxicity to earthworms and terrestrial arthropods due to its chemical group characteristics (strobilurin), as to be relatively readily degraded in the environment causing little potential for chronic exposure (Bartlett et al., 2002). However, the present study revealed a higher sub-lethal effect response of azoxystrobin to earthworms ( $\mathrm{EC}_{50}$ of $42.0 \mathrm{mg}$ a.i. $\mathrm{kg}^{-1} \mathrm{dw}$ natural soil) compared to collembolans and enchytraeids (Table 4). Although a significant biomass decrease was observed on earthworms at the lowest concentration (50 mga.i. $\mathrm{kg}^{-1} \mathrm{dw}$ soil) (Fig. 1), resulting in effects on their reproduction, only $7.7 \%$ mortality was observed at the highest concentration. Even though biomass and mortality are always registered together as test endpoints, Potter et al. (1994) verified that the loss in biomass was independent of the lethal effects of chemicals. The observed low lethal toxicity to earthworms with natural soil differ greatly from the reported results with OECD artificial soil tests showing LC $_{50}$ values of $283 \mathrm{mg}$ a.i. $\mathrm{kg}^{-1}$ soil (EFSA, 2010b) and $327.4 \mathrm{mg}$ a.i. $\mathrm{kg}^{-1}$ soil (Wang et al., 2012). Nevertheless, the fact that the NOEC for earthworms test was not attained with the lowest concentration tested ( $50 \mathrm{mg}$ a.i. $\mathrm{kg}^{-1}$ soil) is in agreement with the reported NOEC of $20 \mathrm{mg}$ a.i. $\mathrm{kg}^{-1}$ soil for E. fetida (FOOTPRINT, 2012).

\subsection{Effects of chlorothalonil on soil biota}

Chlorothalonil is not expected to partition to the soil pore water as active ingredient due to its low solubility in water and high 
sorption constant facilitating adsorption to soil particles (Table 1). However, by using the concentrated suspension formulation, a movement to the soil pore water may be expected due to its water solubility. If present in the water fraction of the soil (soil pore water) the pesticide can be bioavailable for uptake by the soil organisms (Styrishave et al., 2008). In terms of sub-lethal effects of chlorothalonil, collembolans were the most sensitive taxa followed by the earthworms (Table 4). The enchytraeids were the least sensitive with an $\mathrm{EC}_{50}$ ratio of almost 3:1 of the other two organisms. This low sensitivity of enchytraeids towards chlorothalonil has also been reported for other pesticides such as a polychlorinated insecticide in specific and other fungicides of the same chemical group, and insecticides in a broader evaluation (Bezchlebová et al., 2007; Daam et al., 2011b; Frampton et al., 2006). The NOEC for earthworms of $5 \mathrm{mg}$ a.i. $\mathrm{kg}^{-1} \mathrm{dw}$ soil is in agreement with the reported NOEC value of $1.65 \mathrm{mg}$ a.i. $\mathrm{kg}^{-1}$ soil from tests with the same formulation (500 g a.i. $\mathrm{L}^{-1} \mathrm{SC}$ ), and a 5\% OM OECD soil (EC, 2006), which is similar to the organic matter content of the natural soil used in this study (Table 2). The $59 \%$ mortality of adult earthworms observed at the highest tested concentration, of $100 \mathrm{mg}$ a.i. $\mathrm{kg}^{-1} \mathrm{dw}$ soil after 4 weeks exposure to chlorothalonil, occurs at a concentration which is two times lower than the reported earthworms acute test effect concentration ( $\mathrm{LC}_{50}$ ) of $268.5 \mathrm{mg}$ a.i. $\mathrm{kg}^{-1}$ soil (EC, 2006). Although this value is attained from a test with artificial soil with an organic matter content of 5\% (EC, 2006) similar to the tested natural soil, this difference in the lethal effects results may be due to other factors associated to the natural soil such as $\mathrm{pH}$ and clay content influencing pesticide availability (EFSA, 2009b).

\subsection{Effects of ethoprophos on soil biota}

The insecticide ethoprophos by having high solubility in water and low sorption coefficient (Table 1) could be expected to be present in the soil pore water. This movement to the water compartment could also be expected due to the pesticide leaching capacity (GUS; Table 1), and as such, becoming available for uptake by the soil organisms (Styrishave et al., 2008). Collembolans were the most affected by ethoprophos with a low $\mathrm{EC}_{50}$ of $0.027 \mathrm{mg}$ a.i. $\mathrm{kg}^{-1} \mathrm{dw}$ soil, which would be expected from the type of toxic action as an insecticide towards arthropods (Daam et al., 2011b; Frampton et al., 2006). The earthworms presented the second lowest $\mathrm{EC}_{50}$ value of $8.3 \mathrm{mg}$ a.i. $\mathrm{kg}^{-1} \mathrm{dw}$ soil and the enchytraeids were the least sensitive with an $\mathrm{EC}_{50}$ value more than 8 times higher than the collembolan's $\left(\mathrm{EC}_{50}=68.5 \mathrm{mg}\right.$ a.i. $\mathrm{kg}^{-1} \mathrm{dw}$ soil). In spite of such, no mortality effects on adult earthworms were observed and a slight gain in weight was observed. This test results are in congruence with reported values of $\mathrm{LC}_{50} 39.6 \mathrm{mg}$ a.i. $\mathrm{kg}^{-1}$ dw soil (EFSA, 2006) since the maximum tested concentration during this study was $12 \mathrm{mg}$ a.i. $\mathrm{kg}^{-1} \mathrm{dw}$ soil. The observed sub-lethal effects on cocoon production and viability may be a consequence of the pesticide intake by the adults that even at low dosages can cause adverse effects during long term exposures. The reported NOEC value of $<1.67 \mathrm{mg}$ a.i. $\mathrm{kg}^{-1} \mathrm{dw}$ soil (EFSA, 2006) from a test with artificial soil is lower than the study test results, which shows that different soils may cause different toxicity results, as referred above.

\subsection{Sensitivity of the three invertebrate arthropods to the pesticides}

The higher sensitivity of collembolans ( $F$. candida) observed in this study as compared with the other organisms for two pesticides, the fungicide chlorothalonil and the insecticide ethoprophos, has been found for a wide range of pesticides with different type of toxic action, suggesting that the earthworms are not always the most sensitive species (Bezchlebová et al., 2007; Daam et al., 2011b;
Frampton et al., 2006). However, care should be taken when making generalizations of effects of pesticides within the same chemical group where significantly different toxicities may occur in a single group of soil organisms (e.g. effects on earthworms among the strobilurin group (Wang et al., 2012)). Enchytraeids were mainly the least sensitive of the three species tested for reproductive effects. Although reports have shown that they are generally less sensitive than lumbricidae when assessing acute data such as LC $_{50}$ (EFSA, 2009b), the results obtained in our study contradict the results reported by Römbke and Moser (2002) which report a similar sensitivity of the two organism groups regarding reproductive effects in different soil substrates (artificial and natural). These differences in long-term exposure tests reflect the difficulty in grouping pesticides effects on non-target organisms. This emphasizes the need to include arthropods and other annelids as relevant organisms in the first tier of pesticide environmental risk assessment in order to better represent and protect the terrestrial environment against the wide existing group of pesticides (Frampton et al., 2006).

\section{Conclusion}

Results showed that the use of only the earthworm as a key species for the first tier terrestrial ERA of pesticides may not be enough to ascertain a significant protection level of the terrestrial ecosystem by not being the most sensitive organisms, especially for the tested insecticide. Moreover, the use of natural soil may lead to differences in toxicity values compared with OECD referenced values. This illustrates the importance of creating realistic scenarios under the first tier ERA, since artificial soils may not allow a realistic approach for the evaluation of pesticide toxicity. Natural soil variations are accounted for in the Guidance Document on Terrestrial Ecotoxicology (SANCO, 2002) under a risk assessment for earthworms. However, with the revision on the data requirements for active substances (EU, 2013), and the division of the EU territory into three zones (north, central, and south) by the new regulation concerning the placing of plant protection products on the market (EC, 2009), understanding the different behaviour of pesticides and their availability in different soils types becomes of great importance.

\section{Acknowledgements}

This study was partly sponsored by Fundação para a Ciência e Tecnologia, Portugal, through a Ph.D. grant (SFRH/BD/42306/2007). We would like to thank Cátia Silva and all the colleagues at the Soil Ecology and Ecotoxicology Laboratory of Life Sciences Department of Coimbra University for their knowledge and technical support of this study.

\section{References}

Amorim, M.J., Sousa, J.P., Nogueira, A.J.A., Soares, A.M.V.M., 2002a. Bioaccumulation and elimination of 14C-lindane by Enchytraeus albidus in artificial (OECD) and a natural soil. Chemosphere 49, 323-329.

Amorim, M.J., Sousa, J.P., Nogueira, A.J.A., Soares, A.M.V.M., 2002b. Bioavailability and toxicokinetics of $14 \mathrm{C}$-lindane $(\gamma-\mathrm{HCH})$ in the Enchytraeid Enchytraeus albidus in two soil types: the aging effect. Arch. Environ. Contam. Toxicol. 43, 221-228.

Technical guideline, A.S.U.L., 1999. Examination of foodstuff-modular multi-method for the determination of pesticides residues in foodstuff. (expanded revision of the DFG-method S 19).

Bartlett, D.W., Clough, J.M., Godwin, J.R., Hall, A.A., Hamer, M., Parr-Dobrzanski, B. 2002. Review: the strobilurin fungicides. Pest Manag. Sci 58, 649-662.

Bezchlebová, J., Černohlávková, J., Lána, J., Sochová, I., Kobetičová, K., Hofman, J., 2007. Effects of toxaphene on soil organisms. Ecotoxicol. Environ. Saf. 68 326-334.

Chelinho, S., Domene, X., Campana, P., Natal-da-Luz, T., Scheffczyk, A., Römbke, J. Andrés, P., Sousa, J.P., 2011. Improving ecological risk assessment in the Mediterranean area: selection of reference soils and evaluating the influence of soi properties on avoidance and reproduction of the Oligochaete species. Environ. Toxicol. Chem 30, 1050-1058. 
Daam, M.A., Cerejeira, M.J., Van den Brink, P.J., Brock, T.C.M., 2011a. Is it possible to extrapolate results of aquatic microcosm and mesocosm experiments with pesticides between climate zones in Europe? Environ. Sci. Pollut. Res. 18, $123-126$.

Daam, M.A., Leitão, S., Cerejeira Sousa, J.P., 2011b. Comparing the sensitivity of soil invertebrates to pesticides with that of Eisenia fetida. Chemosphere 85, 1040-1047.

De Silva, P.M.C.S., Pathiratne, A., van Gestel, C.A.M., 2009. Influence of temperature and soil type on the toxicity of three pesticides to Eisenia andrei. Chemosphere $76,1410-1415$.

DIN, 1993-2. German Standard Methods for the Determination of Water, Waste Water and Sludge; Jointly Determinable Substances (Group F); Determination of Low Volatile Halogenated Hydrocarbons by Gas Chromatography (F 2). Deutsches Institut für Normung, Berlin, Germany, German Standard DIN 38407F2.

EC, 1998. European Commission, Directorate General for Agriculture, DG VI-B.II-1, azoxystrobin, 7581/VI/97-Final. Review report for the active substance azoxystrobin. European Commission, EU.

EC, 2006. European Commission Health and Consumer protection directorate General, Directorate, D - Food Safety: Production and distribution chain, Unit D.3 - Chemicals, contaminants and pesticides, SANCO/4343/2000 final (revised). Review report for the active substance chlorothalonil.

EC, 2009. Regulation (EC) No 1107/2009 of the European parliament and of the council of 21 October 2009 concerning the placing of plant protection products on the market and repealing council directives 79/117/EEC and 91/414/EEC. Off. J. Eur. Comm. L 309, 1-50.

Edwards, C.A., Bohlen, P.J., 1992. The effects of toxic chemicals on earthworms. Rev. Environ. Contam. Toxicol. 125, 23-99.

EFSA, 2006. Conclusion on the peer review of the pesticide risk assessment of the active substance ethoprophos. EFSA Sci. Rep. 66, 1-72.

EFSA, 2009. Comparison between the sensitivity of Enchytraeids and lumbricidae to chemicals, in particular plant protection products. Final Report CFT/EFSA/PPR/2008/01.

EFSA, 2009b. The usefulness of total concentrations and pore water concentrations of pesticides in soil as metrics for the assessment of ecotoxicological effects. EFSA J. 922.

EFSA, 2010a. Scientific opinion on the development of specific protection goal options for environmental risk assessment of pesticides, in particular in relation to the revision of the guidance documents on aquatic and terrestrial ecotoxicology (SANCO/3268/2001 and SANCO/10329/2002). Eur. Food Saf. Author. (EFSA), Parma, Italy 8 (10), 1821.

EFSA, 2010b. Conclusions on the peer review of the pesticide risk assessment of the active substance azoxystrobin. EFSA J., Parma, Italy 8 (4), 1542, http://www.efsa.europa.eu/en/efsajournal/doc/1542.pdf.

EPS 1/RM/46, 2005. Guidance document on statistical methods for environmental toxicity tests. Method development and applications section. In: Environmental Protection Series. Environment Canada. Environmental Technology Centre, Ottawa, Ontario (with June 2007 amendments).

EU, 2013. Commission Regulation (EU) No 283/2013 of 1 March 2013 setting out the data requirements for active substances, in accordance with Regulation (EC) No 1107/2009 of the European Parliament and of the Council concerning the placing of plant protection products on the market. Off. J. Eur. Union L $93(1)$.

EuDASM, 2011. European Digital Archive Soil Maps 1995-2011. European Commission-Joint Research Centre, Institute for Environment and Sustainability. European Communities, http://eusoils.jrc.ec.europa.eu/library/maps/ country_maps/list_countries.cfm.

FOOTPRINT, 2012 Pesticide Properties Database. Creating tools for pesticide risk assessment and management in Europe. A project funded by the European Commission under the 6th Framework Programme. http://www.eufootprint.org/[last assess 10 December 2012].

Frampton, G.K., Jänsch, S., Scott-Fordsmand, J.J., Römbke, J., Van den Brink, P.J., 2006. Effects of pesticides on soil invertebrates in laboratory studies: a review and analysis using species sensitivity distributions. Environ. Toxicol. Chem. 25, 2480-2489.

Gullino, M.L., Leroux, P., Smith, C.M., 2000. Uses and challenges of novel compounds for plant disease control. Crop Prot. 19, 1-11.

Gustafson, D.I., 1989. Groundwater ubiquity score: a simple method for assessing pesticide leachability. Environ. Toxicol. Chem. 8 (4), 339-357.

ISO 10390, 1994. Soil Quality-Determination of pH-Laboratory Methods. International Organization for Standardization, Paris, France.

ISO 11268-2.2, 1998. Soil Quality-Effects of Pollutants on Earthworms (Eisenia foetida). Part 2: Determination of Effects on Reproduction. International Organization for Standardization, Geneva, Switzerland.

ISO 11267, 1999. Soil Quality-Inhibition of Reproduction of Collembola (Folsomia candida) by Soil. International Organization for Standardization, Geneva, Switzerland.
ISO 16387, 2004. Soil Quality-Effects of Pollutants on Enchytraeidae (Enchytraeus sp.)-Determination of Effects on Reproduction and Survival. International Organization for Standardization, Geneva, Switzerland.

ISO 10695, 2000. Water Quality-Determination of Selected Organic Nitrogen and Phosphorus Compounds-Gas Chromatographic Methods. International Organization for Standardization, Geneva, Switzerland.

ISO 13878,1998 . Soil quality - Determination of total nitrogen content by dry combustion (elemental analysis). International Organization for Standardization, Geneva, Switzerland.

ISO 10694, 1995. Soil quality - Determination of organic and total carbon after dry combustion (elementary analysis). International Organization for Standardization, Geneva, Switzerland.

Karpouzas, D.G., Giannakou, I.O., Walker, A., Gowen, S.R., 1999a. Reduction in biological efficacy of ethoprophos in a soil from Greece due to enhanced biodegradation: comparing bioassay with laboratory incubation data. Pestic. Sci. 55, 1089-1094.

Karpouzas, D.G., Walker, A., Froud-Williams, R.J., Drennan, D.S.H., 1999b. Evidence for the enhanced biodegradation of ethoprophos and carbofuran in soils from Greece and the UK. Pestic. Sci. 55, 301-311.

Kuperman, R.G., Checkai, R.t., Simini, M., Phillips, C.T., 2004. Manganese toxicity in soil for Eisenia fetida Enchytraeus crypticus (Oligochaeta), and Folsomia candida (Collembola). Ecotoxicol. Environ. Saf. 57, 48-53.

Kuperman, R.G., Amorim, M.J.B., Römbke, J., Lanno, R., Checkai, R.T., Dodard, S.G., Sunahara, G.I., Scheffczyk, A., 2006. Adaptation of the enchytraeid toxicity test for use with natural soil types. Eur. J. Soil Biol. 42, 234-243.

Lanno, R., Wells, J., Conder, J., Bradham, K., Basta, N., 2004. The bioavailability of chemicals in soil for earthworms. Ecotoxicol. Environ. Saf. 57, 39-47.

Mackay, D., 2001. Multimedia environmental models: the fugacity approach, Second ed. Lewis Publishers, Boca Raton U.S.A.

OECD (Organization for Economic Co-Operation and Development), 1984. Organization for economic development. Guideline for testing of chemicals no. 207. In: Earthworm Acute Toxicity Test. OECD, Paris France.

Patakioutas, G., Albanis, T.A., 2002. Adsorption-desorption studies of alachlor, metolachlor, EPTC, chlorothalonil and pirimiphos-methyl in contrasting soils. Pest Manag. Sci. 58, 352-362.

Potter, D.A., Spicer, P.G., Redmond, C.T., Powell, A.J., 1994. Toxicity of pesticides to earthworms in Kentucky bluegrass turf. Bull. Environ. Contam. Toxicol. 52, $176-181$.

Römbke, J., Moser, Th., 2002. Validating the enchytraeid reproduction test: organisation and results of an international ringtest. Chemosphere 46, 1117-1140.

Ramos, C., Carbonell, G., García Baudín, J.Ma., Tarazona, J.V., 2000. Ecological risk assessment of pesticides in the Mediterranean region. The need for crop-specific scenarios. Sci. Total Environ. 247, 269-278.

Sakkas, V.A., Lambropoulou, D.A., Albanis, T.A., 2002. Study of chlorothalonil photodegradation in natural waters and in the presence of humic substances. Chemosphere 48, 939-945.

Sánchez-Moreno, S., Alonso-Prados, E., Alonso-Prados, J.L., García-Baudín, J.M., 2009. Multivariate analysis of toxicological and environmental properties of soil nematicides. Pest. Manag. Sci. 65, 82-92

SANCO 2002. DRAFT Working Document-Guidance Document on Terrestrial Ecotoxicology Under Council Directive 91/414/EEC. SANCO/10329/rev 2 final. European Commission Health \& Consumer Protection Directorate-General, Directorate E-Food Safety: plant health, animal health and welfare, international questions, E1-Plant health. 2002.

Stat Soft Inc, 2004. STATISTICA 7.0 Data analysis software system, version 7, www.statsoft.com.

Styrishave, B., Mortensen, M., Krogh, P.H., Andersen, O., Jensen, J., 2008. Solid-phase microextraction (SPME) as a tool to predict the bioavailability and toxicity of pyrene to the Springtail Folsomia candida, under various soil conditions. Environ. Sci. Technol. 42, 1332-1336.

MacBean, C., 2012. The Pesticide Manual, 16th Ed. Hampshire, BCPC.

Tu, C., Wang, Y., Duan, W., Hertl, P., Tradwaya, L., Brandenburgd, R., Lee, D., Snell, M., Hu, S., 2011. Effects of fungicides and insecticides on feeding behavior and community dynamics of earthworms: implications for casting control in turf grass systems. Appl. Soil Ecol. 47, 31-36.

Van Gestel, C.A., Borgman, E., Verweij, R.A., Ortiz, M.D., 2011. The influence of soil properties on the toxicity of molybdenum to three species of soil invertebrates. Ecotoxicol. Environ. Saf. 74 (1), 1-9.

Van Gestel, C.A.M., 2012. Soil ecotoxicology: state of the art and future directions. In: Štrus, J., Taiti, S., Sfenthourakis, S. (Eds.), Advances in Terrestrial Isopod Biology, 176. ZooKeys, pp. 275-296.

Wang, Y., Wu, S., Chen, L., Wu, C., Yu, R., Wang, Q., Zhao, X., 2012. Toxicity assessment of 45 pesticides to the epigeic earthworm Eisenia fetida. Chemosphere 88, 484-491.

Wilcox, D., Dove, B., McDavid, D., Greer, D., 2002. UTHSCSA Image Tool version 3.00, University of Texas Health Science Center in San Antonio. UTHSCSA, compdent.uthscsa.edu/dig/download.html. 